\title{
Spectrophotometric method for palladium determination using 5-hydroxyimino-4-imino-1,3-thiazolidin-2-one and application to the analysis of intermetallides
}

\author{
Lesya LOZYNSKA ${ }^{1}$, Oleksandr TYMOSHUK ${ }^{1}$, Petro RYDCHUK ${ }^{1}$ \\ ${ }^{1}$ Department of Analytical Chemistry, Faculty of Chemistry, Ivan Franko National University of Lviv, \\ Kyryla i Mefodiya St. 6, 79005 Lviv, Ukraine \\ * Corresponding author.Tel.: +380-32-2394048; e-mail: l_lozynska@ukr.net
}

Dedicated to Evgen I. Gladyshevskii (1924-2012)

Received February 10, 2014; accepted June 26, 2014; available on-line November 10, 2014

This work describes the application of a new, simple and rapid spectrophotometric method to the determination of palladium in the intermetallides $Y_{b_{40}} \mathbf{P d}_{38} S_{22}$ and $\mathbf{Y b}_{40} \mathbf{P d}_{40} \mathbf{G a}_{20}$. The method is based on the interaction of palladium(II) ions with 5-hydroxyimino-4-imino-1,3-thiazolidin-2-one at $p H=5.0$, in a medium of acetate buffer and sodium chloride. The range of the determined concentrations of palladium is $6.0 \cdot 10^{-6}-6.0 \cdot 10^{-5} \mathrm{M}$.

Intermetallides / Palladium(II) / Spectrophotometry / 5-hydroxyimino-4-imino-1,3-thiazolidin-2-one

\section{Introduction}

Palladium-containing materials possess valuable chemical and physical properties. Consequently, they play an important role in different industries. Palladium and its alloys have a wide range of applications, both in chemical industry and in instrumentation. They also have widespread use in dental and medical devices and the manufacture of jewelry. Palladium and palladium-based alloys can store hydrogen isotopes at moderate temperatures and pressures [1]. In the last few years, palladium has been used as one of the components of a three-component catalyst for automobile exhaust fumes [2]. Palladiumbased alloys are widely used in dentistry $[3,4]$. The evaluation of the palladium content in intermetallides obtained after fusion and other samples is an important task and requires the development of new methods for reliable determination in a wide range of concentrations.

One of the common methods for the determination of palladium is spectrophotometry, the main advantages of which are simplicity, accessibility and rapidity. There exist many spectrophotometric methods for the determination of palladium, using organic or inorganic reagents, but they have some limitations [5,6]. Therefore, the search for new accessible, selective and sensitive reagents, which would make it possible to determine the palladium content also in complex objects, is an important task.
Among the large number of known reagents, azolidons and their derivatives, which contain functional groups with electron donor atoms $\mathrm{S}, \mathrm{N}, \mathrm{O}$ [7], have attracted special interest. Rodanine, which belongs to the class of azolidons, and its derivatives are successfully used in analytical practice as reagents for the determination of noble and heavy metals [8-14].

We used a new organic reagent, 5-hydroxyimino4-imino-1,3-thiazolidin-2-one (HITO), for the spectrophotometric determination of palladium. It was found that HITO forms a new compound with $\mathrm{Pd}(\mathrm{II})$ ions $[15,16]$, a sufficiently stable complex with the components in the ratio $1: 1$. The optimal conditions for the formation of this compound and some of its spectrophotometric characteristics are reported in Table 1. This method is simple and rapid. The intensity of the analytical signal used in the spectrophotometric determination of palladium(II) with HITO depends linearly on the concentration of metal ion in solution. The metrological characteristics of the developed method are presented in Table 2 ( $n=$ number of parallel experiments, $P=$ confidence probability). The method of spectrophotometric determination of palladium(II) using 5-hydroxyimino4-imino-1,3-thiazolidin-2-one is characterized by good sensitivity and can be used in a wide concentration range of the metal. We have now applied this method to the determination of palladium in two alloys of composition $\mathrm{Yb}_{40} \mathrm{Pd}_{38} \mathrm{Sn}_{22}$ and $\mathrm{Yb}_{20} \mathrm{Pd}_{2} \mathrm{Ga}_{78}$. 
Table 1 Spectrophotometric characteristics of compound of $\mathrm{Pd}(\mathrm{II})$ with HITO.

\begin{tabular}{c|c|c|c|c|c}
\hline$\lambda_{\text {opt. }}, \mathrm{nm}$ & $p H_{\text {opt. }}$ & $\varepsilon_{\lambda}, \mathrm{L} \cdot \mathrm{mol}^{-1} \cdot \mathrm{cm}^{-1}$ & Me:L & $\lg \beta$ & $t_{\text {heat. }}$, min \\
\hline 350 & 5.0 & $5.9 \cdot 10^{3}$ & $1: 1$ & 6.0 & 10 \\
\hline
\end{tabular}

Table 2 Metrological characteristics of the spectrophotometric determination of palladium(II) with HITO $\left(C_{\mathrm{HITO}}=8.0 \cdot 10^{-5} \mathrm{M} ; C_{\mathrm{NaCl}}=0.1 \mathrm{M} ; C_{\mathrm{CH} 3 \mathrm{COONa}}=0.32 \mathrm{M} ; p \mathrm{H}=5.0 ; l=1.0 \mathrm{~cm} ; \lambda=350 \mathrm{~nm} ; n=5 ; P=0.95\right)$.

\begin{tabular}{c|c|c|c|c}
\hline Linearity, $\mathrm{M}$ & $\begin{array}{c}\text { Calibration equation, } \\
C_{\mathrm{Pd}}, \mathrm{M}\end{array}$ & $C_{\min }, \mathrm{M}$ & $C_{\lim }, \mathrm{M}$ & $\begin{array}{c}\text { Correlation coefficient, } \\
R\end{array}$ \\
\hline $6.0 \cdot 10^{-6}-6.0 \cdot 10^{-5}$ & $\Delta A_{350}=0.012+6260 C_{\mathrm{Pd}}$ & $2.1 \cdot 10^{-6}$ & $6.3 \cdot 10^{-6}$ & 0.998 \\
\hline
\end{tabular}

\section{Experimental}

All the aqueous solutions used in the research were prepared using distilled water. All the chemicals were of analytical grade.

A stock solution of $\mathrm{Pd}(\mathrm{II})$ was prepared by dissolving metallic palladium $(99.999 \%)$ in a mixture of concentrated $\mathrm{HNO}_{3}$ and $\mathrm{HCl}$ (1:3). Standard $\mathrm{Pd}(\mathrm{II})$ solutions were prepared by dissolving an aliquot of palladium(II) stock solution in $1.0 \mathrm{M} \mathrm{HCl}$.

A solution of 5-hydroxyimino-4-imino1,3-thiazolidin-2-one was prepared by dissolving the accurate weight of the reagent in $96 \%$ v/v ethanol.

Solutions of $\mathrm{CH}_{3} \mathrm{COONa}, \mathrm{NaCl}$ and $\mathrm{NaOH}$ were prepared by dissolving appropriate amounts of $\mathrm{CH}_{3} \mathrm{COONa}, \mathrm{NaCl}$ and $\mathrm{NaOH}$ in water. The solution of $\mathrm{HCl}$ was prepared by dilution of concentrated $\mathrm{HCl}$.

Absorption spectra were recorded using a $108 \mathrm{UV} / \mathrm{ULAB}$ spectrophotometer and a $1 \mathrm{~cm}$ quartz cell. All of the absorbance measurements were performed at $\sim 20^{\circ} \mathrm{C}$.

The $p H$ measurements were carried out with a $\mathrm{pH}$-meter, model $\mathrm{pH}-150 \mathrm{M}$, equipped with a combination glass electrode (Gomelsky Plant of Measuring Devices, Belarus).

Voltammetric investigations were carried out using a CLA-03 oscillopolarograph with a digital setup, equipped with a computer and a three-electrode thermostated cell (electrode-indicator, cathode a drop mercury electrode; reference electrode, anode a mercury chloride (saturated calomel) electrode; auxiliary electrode - platinum) using linear potential sweep. Dissolved oxygen was removed from the investigated solutions by passing argon for $15 \mathrm{~min}$.

Activation of the solutions was performed by thermal treatment in a boiling water bath.

\section{Results and discussion}

The method of spectrophotometric determination of palladium using 5-hydroxyimino-4-imino1,3-thiazolidin-2-one was applied to the analysis of the ternary intermetallic systems $\mathrm{Yb}_{40} \mathrm{Pd}_{38} \mathrm{Sn}_{22}$ $\left(\omega_{\mathrm{Pd}}=29.8 \% \quad(\mathrm{w} / \mathrm{w})\right) \quad$ and $\quad \mathrm{Yb}_{40} \mathrm{Pd}_{40} \mathrm{Ga}_{20}$ $\left(\omega_{\mathrm{Pd}}=33.9 \%(\mathrm{w} / \mathrm{w})\right)$. Before using the technique to determine palladium in real samples, including intermetallics, it was necessary to investigate the selectivity of the method. Therefore the influence of the most common related ions and some masking agents was investigated. The results of this study are shown in Table 3. As seen from this table, the developed method is characterized by good selectivity, since even when present in large amounts, alkalineearth metals, $\mathrm{Ni}(\mathrm{II}), \mathrm{Co}(\mathrm{II}), \mathrm{Pb}(\mathrm{II}), \mathrm{Cd}(\mathrm{II}), \mathrm{Zn}$ (II), and other ions that are often included in palladiumcontaining objects, do not interfere. The selectivity relative to $\mathrm{Cu}$ (II) and $\mathrm{Fe}$ (III) ions (from 5-fold to 40-fold excess) could be improved by using one of the following masking agents: EDTA, $\mathrm{Citr}^{3-}, \mathrm{Tart}^{2-}, \mathrm{PO}_{4}{ }^{3-}$. It was also possible to increase the selectivity in regard to ruthenium(IV), using EDTA $\left(C_{\mathrm{Pd}(\mathrm{II})}: C_{\mathrm{Ru}(\mathrm{IV})}=1: 1\right) . \mathrm{Ga}(\mathrm{III}), \mathrm{Sn}(\mathrm{II})$ and $\mathrm{Yb}(\mathrm{III})$ ions, in the amounts contained in the studied intermetallides, do not interfere with the determination of palladium.

\section{Dissolution of the intermetallide samples}

The alloys were dissolved in a mixture of concentrated $\mathrm{HCl}$ and $\mathrm{HNO}_{3}$ (3:1) under heating. To obtain solutions of the analytes, 0.1-0.2 $\mathrm{g}$ of the intermetallic alloy were dissolved in $10-20 \mathrm{ml}$ of a mixture of the above-mentioned acids. The mixture was boiled in a beaker in a sand bath for 1-2 hours. The dry residue was dissolved in a $2.5 \mathrm{M} \mathrm{HCl}$ solution and transferred into a $100.0 \mathrm{ml}$ volumetric flask.

\section{Determination of palladium in intermetallides}

For the analysis, aliquots of $0.2-0.3 \mathrm{ml}$ were taken. The palladium content was evaluated using the method of normal calibration curve, by means of an appropriate analytical procedure of determination. The duration of an analysis without preliminary sample preparation was approximately 1 hour.

Procedure for determining palladium: $0.25 \mathrm{ml}$ of the $8.0 \cdot 10^{-3} \mathrm{M}$ ethanolic solution of HITO and the aliquots of $\mathrm{Pd}(\mathrm{II})$ solution, containing $6.0 \cdot 10^{-6}$ $6.0 \cdot 10^{-5} \mathrm{M}$ of palladium in the final volume, were placed into a beaker. Then $2.0 \mathrm{ml}$ of $4.0 \mathrm{M}$ sodium acetate and $1.25 \mathrm{ml}$ of $2.0 \mathrm{M}$ sodium chloride were added to maintain constant ionic strength. Distilled water was poured to a total volume of $\sim 15-20 \mathrm{ml}$. 
Table 3 Tolerance ratios of interfering ions during the spectrophotometric determination of $\mathrm{Pd}(\mathrm{II})$ in the presence of HITO $\left(C_{\mathrm{HITO}}=8.0 \cdot 10^{-5} \mathrm{M} ; C_{\mathrm{Pd}(\mathrm{II})}=2.0 \cdot 10^{-5} \mathrm{M} ; C_{\mathrm{NaCl}}=0.1 \mathrm{M} ; C_{\mathrm{CH} 3 \mathrm{COONa}}=0.32 \mathrm{M} ; p \mathrm{H}=5.0\right.$; $l=1.0 \mathrm{~cm} ; \lambda=350 \mathrm{~nm})$.

\begin{tabular}{c|c|c|c|c|c}
\hline Ion & $C_{\text {Ion }}: C_{\mathrm{Pd}(\mathrm{II})}$ & $\mathrm{Ion}$ & $C_{\text {Ion }}: C_{\mathrm{Pd}(\mathrm{II})}$ & $\mathrm{Ion}$ & $C_{\mathrm{Ion}}: C_{\mathrm{Pd}(\mathrm{II})}$ \\
\hline $\mathrm{Yb}(\mathrm{III})$ & $1:>200$ & $\mathrm{Fe}(\mathrm{III})$ & $1: 0.5$ & $\mathrm{Mg}(\mathrm{II})$ & $1:>200$ \\
$\mathrm{Sn}(\mathrm{II})$ & $1: 3$ & $\mathrm{Mn}(\mathrm{II})$ & $1:>200$ & $\mathrm{Citr}^{3-}$ & $1:>200$ \\
$\mathrm{Ga}(\mathrm{III})$ & $1: 15$ & $\mathrm{Cu}(\mathrm{II})$ & $1: 0.6$ & Sal $^{-}$ & $1: 100$ \\
$\mathrm{Ru}(\mathrm{IV})$ & $1: 0.2$ & $\mathrm{Cd}(\mathrm{II})$ & $1: 100$ & Tart $^{2-}$ & $1:>200$ \\
$\mathrm{Rh}(\mathrm{III})$ & $1: 0.25$ & $\mathrm{Zn}(\mathrm{II})$ & $1:>200$ & $\mathrm{EDTA}^{-}$ & $1:>200$ \\
$\mathrm{Pt}(\mathrm{IV})$ & $1: 1$ & $\mathrm{~Pb}(\mathrm{II})$ & $1: 100$ & $\mathrm{~F}^{-}$ & $1:>200$ \\
$\mathrm{Ir}(\mathrm{IV})$ & $1: 1$ & $\mathrm{Al}(\mathrm{III})$ & $1: 30$ & $\mathrm{PO}_{4}{ }^{3-}$ & $1:>200$ \\
$\mathrm{Ni}(\mathrm{II})$ & $1: 150$ & $\mathrm{Ba}(\mathrm{II})$ & $1: 100$ & $\mathrm{C}_{2} \mathrm{O}_{4}{ }^{2-}$ & $1:>200$ \\
$\mathrm{Co}(\mathrm{II})$ & $1: 50$ & $\mathrm{Ca}(\mathrm{II})$ & $1:>200$ & $\mathrm{SiO}_{3}{ }^{2-}$ & $1:>200$ \\
\hline
\end{tabular}

Table 4 Results of the determination of palladium in the alloys $\left(S_{r}\right.$ - relative standard uncertainty); $n=3$, $P=0.95$.

\begin{tabular}{c|c|c|c|c|c}
\hline \multirow{2}{*}{ Intermetallide } & \multirow{2}{*}{$\omega_{P d}^{\text {calc }}, \%(\mathrm{w} / \mathrm{w})$} & $\bar{\omega}_{P d}^{p r} \pm \frac{S \cdot t_{\alpha}}{\sqrt{n}}, \%(\mathrm{w} / \mathrm{w})$ & $S_{r}, \%$ & $\bar{\omega}_{P d}^{p r} \pm \frac{S \cdot t_{\alpha}}{\sqrt{n}}, \%(\mathrm{w} / \mathrm{w})$ & $S_{r}, \%$ \\
\cline { 3 - 6 } & 29.8 & $30.6 \pm 0.9$ & 1.2 & $30.2 \pm 0.8$ & 1.1 \\
$\mathrm{Yb}_{40} \mathrm{Pd}_{38} \mathrm{Sn}_{22}$ & 33.9 & $34.2 \pm 0.7$ & 0.8 & $34.3 \pm 0.6$ & 0.7 \\
$\mathrm{Yb}_{40} \mathrm{Pd}_{40} \mathrm{Ga}_{20}$ & & 34.8 & \multicolumn{2}{|c|}{ Soltammetry } \\
\hline
\end{tabular}

Then the $p H$ value was adjusted $(p H=5.0)$ by adding $\mathrm{CH}_{3} \mathrm{COOH}$ or $\mathrm{CH}_{3} \mathrm{COONa}$. After that, the solution was transferred to a volumetric flask of $25.0 \mathrm{ml}$ and adjusted to the mark with distilled water. The solutions were heated in a boiling water bath $\left(\sim 98^{\circ} \mathrm{C}\right)$ for $10 \mathrm{~min}$. After cooling to room temperature $\left(\sim 20^{\circ} \mathrm{C}\right)$, absorbance measurements were carried out against a blank solution at $350 \mathrm{~nm}$ in $1.0 \mathrm{~cm}$ cuvettes. The results are presented in Table 4 . It is seen that the results correlate well with the nominal palladium content in the alloys. The values of the relative standard deviations, $S_{r}$ do not exceed the typical values for spectrophotometric analyses. The correctness of the results of the determination of palladium in the intermetallic compounds was checked using the voltammetric method (Table 4). Palladium was determined by voltammetry during reduction $(U=-0.82 \mathrm{~V})$ of its ammine complex $\left(\left[\mathrm{Pd}\left(\mathrm{NH}_{3}\right)_{4}\right]^{2+}\right)$ on the dropping mercury electrode [6].

\section{Conclusions}

A new spectrophotometric method for the determination of Pd(II), using HITO, was successfully applied to measure the content of this platinum metal in two intermetallides. The method is characterized by good selectivity and the analysis does not interfere with most concomitant ions. The procedure of determining the palladium content in alloys is simple, rapid, and does not require the use of masking agents, or previous separation of the analyte from other components of the intermetallides. The results correlate with the nominal content of palladium in the alloys, and were confirmed by voltammetry.

\section{Acknowledgements}

The authors would like to thank Prof. Yu.M. Grin and Associate Prof. T.Ya. Vrublevska for providing the intermetallic samples.

\section{References}

[1] F.A. Lewis, Int. J. Hydrogen Energy 21(6) (1996) 461-464.

[2] F. Klingstedt, A.K. Neyestanaki, R. Byggningsbacka, L.-E. Lindfors, M. Lundén, M. Petersson, P. Tengström, T. Ollonqvist, J. Väyrynen, Appl. Catal., A 209 (2001) 301-316.

[3] M. Syverud, J.E. Dahl, H. Herø, E. Morisbak, Dent. Mater. 17(1) (2001) 7-13.

[4] S. Viennot, M. Lissac, G. Malquarti, F. Dalard, B. Grosgogeat, Acta Biomater. 2(3) (2006) 321-330.

[5] Yu.A. Zolotov, G.M. Varshal, V.M. Ivanov (Eds.), Analytical Chemistry of Platinum Group Metals, Collected Articles, Editorial URSS, Moscow, 2003, 592 p. (in Russian).

[6] S.I. Ginzburg, N.A. Yezerskaya, I.V. Prokofyeva, N.V. Fedorenko, V.I. Shlenskaya, N.K. Belsky, Analytical Chemistry of Platinum Group Metals, Nauka, Moscow, 1972, 613 p. (in Russian). 
L. Lozynska et al., Spectrophotometric method for palladium determination using 5-hydroxyimino-4-imino-...

[7] R.S. Lebedev, Russ. Phys. J. 45(8) (2002) 822-830.

[8] S.B. Savvin, R.F. Gur'eva, Zh. Anal. Khim. 35(9) (1980) 1818-1830.

[9] R.F. Gur'eva, S.B. Savvin, Zh. Anal. Khim. 46(7) (1991) 1307-1311.

[10] R.F. Gur'eva, S.B. Savvin, Usp. Khim. 67(3) (1998) 236-251.

[11] S.B. Savvin, R.F. Gur'eva, Talanta 34(1) (1987) 87-101.

[12] E. Tang, G. Yang, J. Yin, Spectrochim. Acta, Part A 59(3) (2003) 651-656.
[13] S.B. Savvin, R.F. Gur'eva, Zh. Anal. Khim. 57(11) (2002) 1158-1175.

[14] G. Alfonso, J. Ariza, Microchem. J. 26(4) (1981) 574-585.

[15] L.V. Lozynska, Coll. Abstr. Anal. Chem. VII Russ. Conf. Young Scientists Students Int. Part. Chem. Nanotechn., St. Petersburg, Russia, 2013, pp. 55-56 (in Russian).

[16] L. Lozynska, O. Tymoshuk, Chem. Chem. Technol. 7(4) (2013) 391-395. 